\title{
Effects of Irrigation, Nitrogen Fertilization, Plant Population and Variety on the Physico-Chemical Properties of Maryland Tobacco
}

\author{
by Gerald W. Brown, Claude G. McKee, and Orman E. Street** \\ Agricultural Experiment Station, Department of Agronomy, College of Agriculture, \\ University of Maryland, College Park, Maryland, USA
}

\section{Agronomic Effects*}

\section{INTRODUCTION}

The acceptability of Maryland tobacco to the cigarette industry depends to a large degree on the unique physico-chemical properties of the leaf. These properties are due to climatic and soil factors, to genetic material, and finally to fertilization, cultural, curing and fermentation practices.

Nearly all quality characteristics of Maryland tobacco are improved by supplemental irrigation. Both foreign and domestic cigarette manufacturers desire leaf with the light colors, fluffy body and open texture that can only by obtained when tobacco has been grown with an adequate supply of moisture. Uninterrupted growth is necessary if a thick, tight-grained leaf is to be avoided.

Summer rainfall in the tobacco producing area of Maryland is mostly thundershowers, erratic in both distribution and amount.

Drought periods of many months occur frequently in the Atlantic Coast states. Fieldhouse and Palmer (3) have studied the meteorological and agricultural drought of the Northeastern states for the period of 1929 through 1963, a total of 35 years. Based on potential evapotranspiration losses, their method classifies the severity of drought as incipient, mild, medium, severe and extreme. On this basis in the five counties of Southern Maryland in which tobacco is grown, 51 per cent of the months had a rainfall deficiency, of which I7.5 per cent had medium to extreme drought.

If the amounts of other fertilizer elements are not deficient, the amount of nitrogen supplied to the plant largely determines the yield and quality of cured leaf, including color and body. Nitrogen nutrition also

\footnotetext{
* Presented at the 5th International Tobacco Scientific Congress, Hamburg, September 1970

Contribution No. 4333, Scientific Article No. A 1608, of the University of Maryland Agricultural Experiment Station. Portions of these data were submitted by the senior author to the Graduate School, University of Maryland, in partial fulfillment of the requirements for the Master of Science degree.

$*$ Formerly graduate student, Department of Agronomy, now at Virginia Polytechnic Institute, College of Agriculture, Blacksburg, Virginia; Associate Professor, and Emeritus Professor of Agronomy, University of Maryland.
}

affects the chemical composition, especially the nitrogenous compounds, including the alkaloids. Duration of burn or fire-holding capacity, and filling capacity or specific volume, are also affected by rate of nitrogen fertilization, as well as by water supply.

Within a considerable range, plants of tobacco tend to compensate for differences in spacing, or for occasional missing plants. Woltz and Mason (7) studying this problem have shown an interaction of plant spacing and height of topping of flue-cured tobacco.

Standard Maryland varieties Wilson and Catterton were used in this study.

Wilson variety of Maryland tobacco is the basic true broadleaf type, with short internodes, broad leaves and a drooping habit of growth. Catterton variety of Maryland tobacco is a medium broadleaf, with wider internodes, a somewhat narrower leaf and a more rapid early growth. Both are farmer selections, although the Catterton variety may have been an "escape" from an early breeding program in which crosses between Maryland broadleaf and Burley were being studied [Bowoling et al. (I)].

\section{EXPERIMENTAL CONDITIONS}

Tests of supplemental irrigation for tobacco were started in 1955 at the University of Maryland Tobacco Experimental Farm, Upper Marlboro, Maryland, USA. These tests have continued without interruption until the present time, with some modifications.

A split plot design having irrigation versus non-irrigation as the main plot was used. The other treatments, nitrogen rate, variety and spacing, were used in a completely randomized block design, with all treatments appearing in each main plot. Four replications were used. Analysis of variance of the results followed conventional lines.

The soil was classified as Monmouth fine sandy loam, a moderately deep, light textured, well drained soil with a moderately permeable surface soil. A less permeable subsoil occurs at depths from 30 to $50 \mathrm{~cm}$ restricting the downward movement of water. The soil has a high content of glauconite and is well adapted to the production of tobacco. 
Supplemental irrigation was applied by the modified Skinner overhead pipe system capable of delivering about $.85 \mathrm{~cm}$ of water per hour. The irrigation pipes could be rotated in an arc up to $180^{\circ} \mathrm{C}$, and could distribute the water to a width of 9 meters on each side of the line.

Nitrogen rates were 100.9, 134.5 and $168.1 \mathrm{~kg} / \mathrm{ha}$. Commercially prepared granular 4-8-12 analysis fertilizer was used at a rate of $2522.5 \mathrm{~kg} / \mathrm{ha}$. This supplied $100.9 \mathrm{~kg} / \mathrm{ha}$ of nitrogen, $201.8 \mathrm{~kg} / \mathrm{ha}$ of phosphoric acid $\left(\mathrm{P}_{2} \mathrm{O}_{5}\right)$, and $302.7 \mathrm{~kg} / \mathrm{ha}$ of potash $\left(\mathrm{K}_{2} \mathrm{O}\right)$, and was uniformly used in a broadcast application on all plots. The higher rates of nitrogen application were obtained by the addition of ammonium nitrate and urea, each supplying half of the added nitrogen.

Individual plots were $5.867 \mathrm{~m}$ long and $7.468 \mathrm{~m}$ wide, an area of 43.81 square meters per plot. Seven rows, $1.067 \mathrm{~m}$ apart, and running parallel with the irrigation line, constituted a plot. Plant spacings in the row were $.533 \mathrm{~m}$ and $.419 \mathrm{~m}$, allowing 11 and 14 hills per row for the two spacings. Plant populations were 17584 and 22371 per hectare. In harvesting, the two outside rows were removed, as were the end plants of the inner rows, leaving 45 and 60 plants per plot for the experimental samples.

A winter cover crop of winter wheat was plowed in March or April, and the land kept free of weeds by discing until planting in early June. The application of the broadcast fertilizer was followed by a light discing and marking of the plots for planting. Cultivation and handhoeing was practiced as needed. Topping was delayed until the plants were nearly all in full flower. Harvest by stalk cutting followed in 10 days to two weeks after topping. The plants were speared onto sticks, hung in the barn and air-cured for about 12 weeks before grading.

Following curing, tobacco from each plot was sorted into four farmer grades: seconds, bright, dull bright and dull, representing the four stalk positions from bottom to top of the plant. Representative sample hands from each plot were assigned a government grade by the Tobacco Division, Agricultural Marketing Service, U. S. Department of Agriculture. A 5-yearaverage market price of grades served as a basis for determining unit value of the samples, as well as total value.

\section{Soil Moisture Determinations}

Soil moisture levels during the growing season were determined by two methods, the Bouyoucous gypsum blocks as described by Slater (6), and the tensiometer described by Richards (5). The tensiometers were placed at two depths, a shallow placement with the bottom of the cup at $20 \mathrm{~cm}$, and a deeper one at $30 \mathrm{~cm}$. The gypsum blocks were buried at 10, 20, 30 and $50 \mathrm{~cm}$. Resistance readings were taken with an appropriate ohmmeter three times a week. These were calculated to percentage soil moisture on a weight basis. Applications of irrigation were scheduled according to the moisture levels as determined by both methods.
Figure 1. Bouyoucous moisture block readings taken at 10-centimeter depth measured in per cent moisture. Rainfall and irrigation measured in centimeters for 1964.
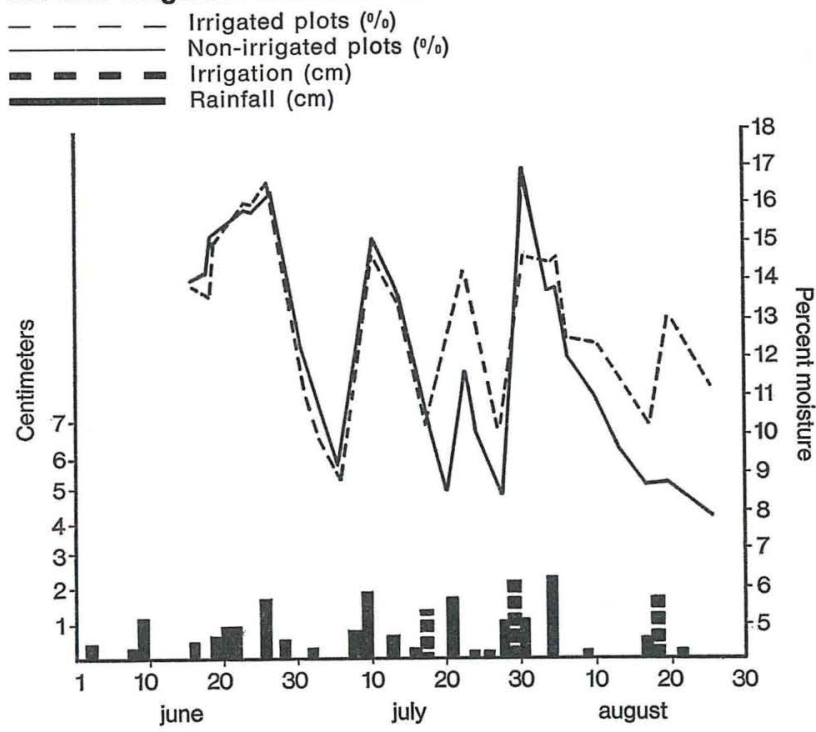

Figure 2. Bouyoucous moisture block readings taken at 20-centimeter depth measured in per cent moisture. Rainfall and irrigation measured in centimeters for 1964.

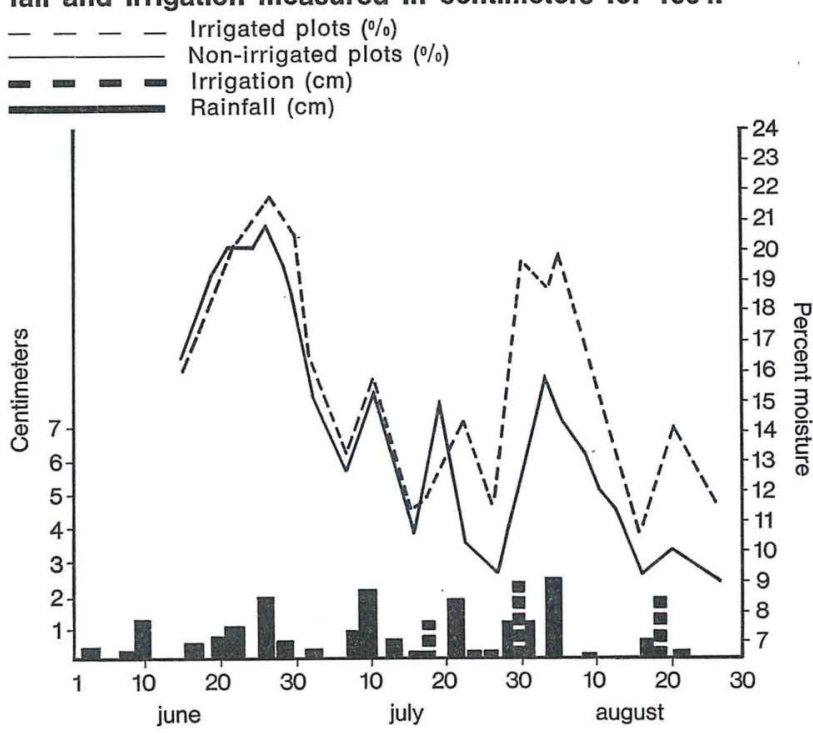

Figure 3. Bouyoucous moisture block readings taken at 30-centimeter depth measured in per cent moisture. Rainfall and irrigation measured in centimeters for 1964.

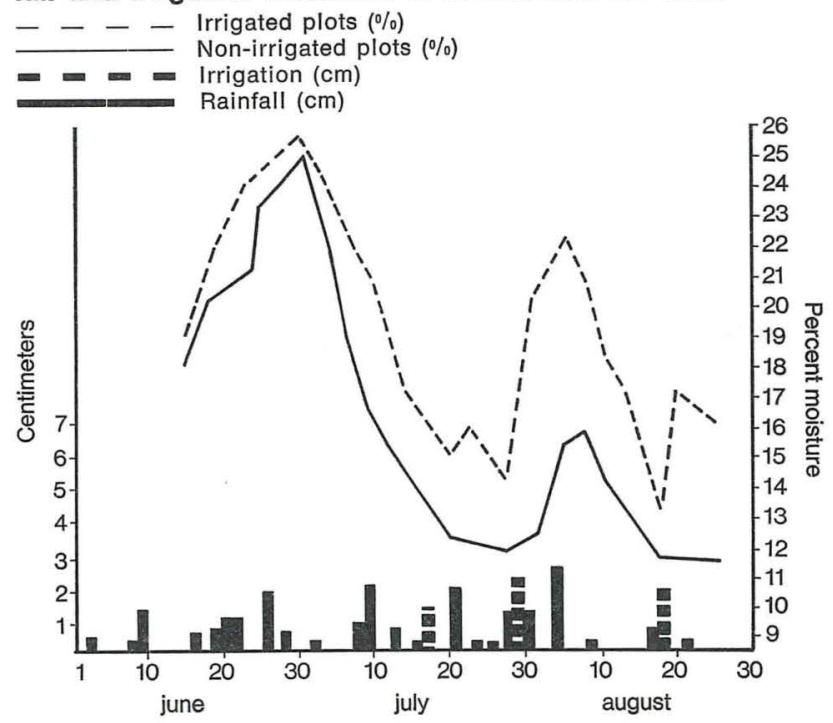


Figure 4. Bouyoucous moisture block readings taken at 50-centimeter depth measured in per cent moisture. Rainfall and irrigation measured in centimeters for 1964.

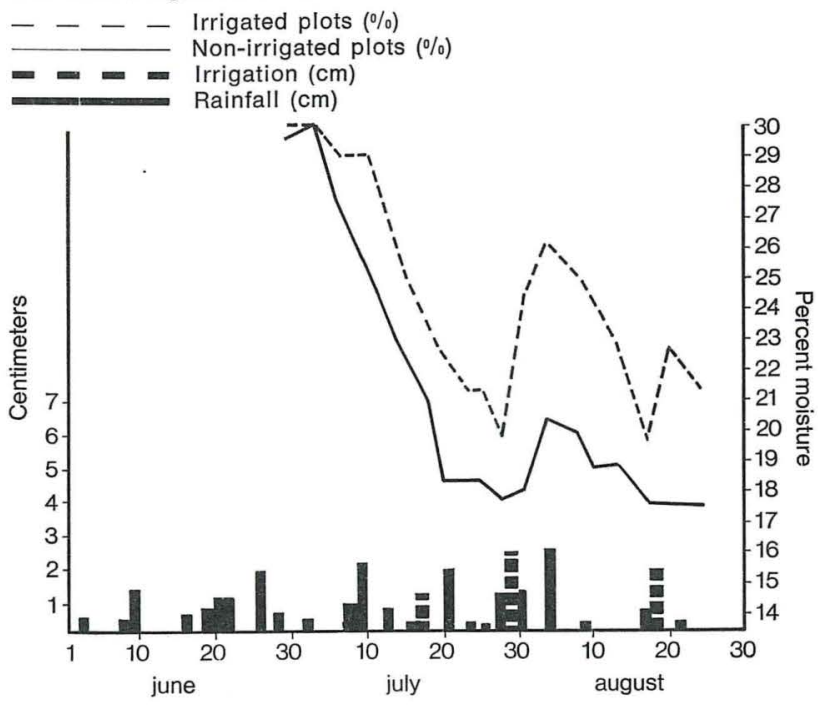

Figure 5. Bouyoucous moisture block readings taken at 10 -centimeter depth measured in per cent moisture. Rainfall and irrigation measured in centimeters for 1965.

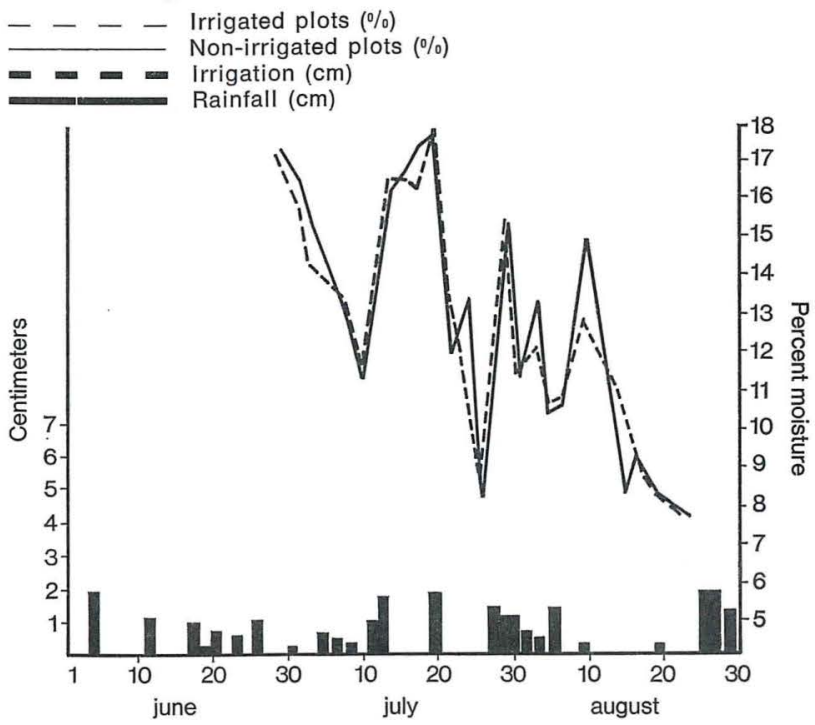

Figure 6. Bouyoucous moisture block readings taken at 20-centimeter depth measured in per cent moisture. Rainfall and irrigation measured in centimeters for 1965.

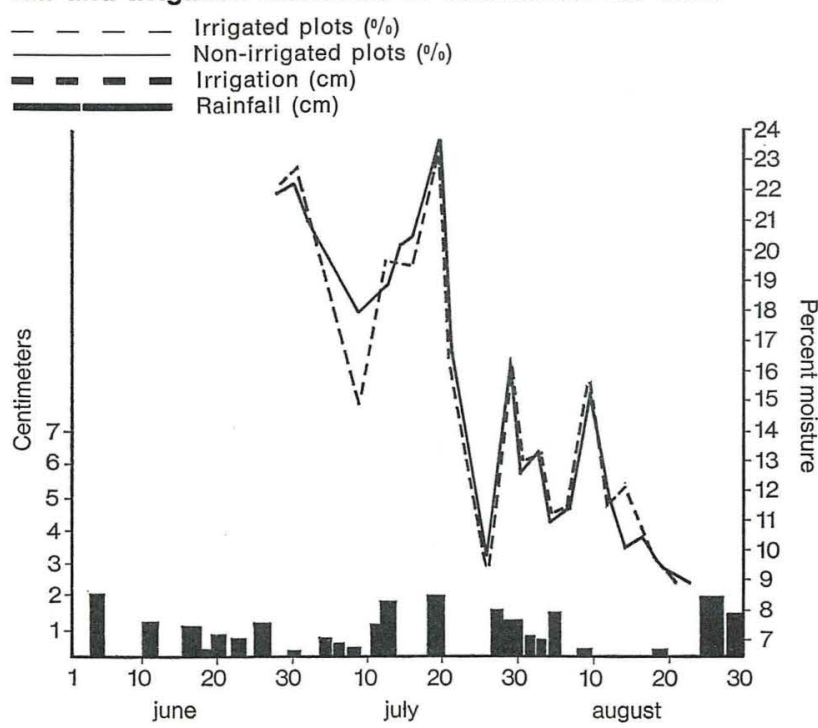

Figure 7. Bouyoucous moisture block readings taken at 30-centimeter depth measured in per cent moisture. Rainfall and irrigation measured in centimeters for 1965.

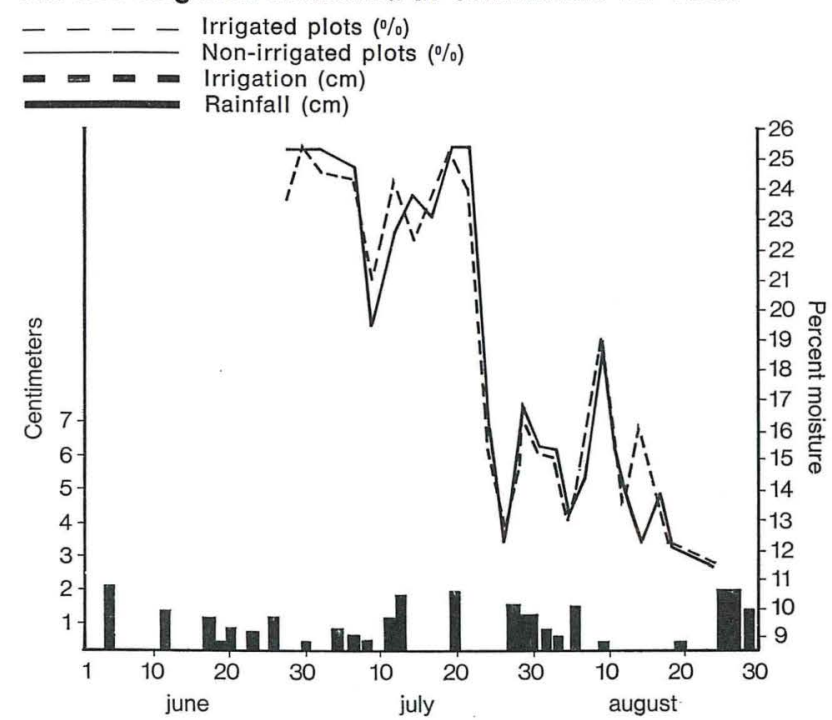

Figure 8. Bouyoucous moisture block readings taken at 50-centimeter depth measured in per cent moisture. Rainfall and irrigation measured in centimeters for 1965 .

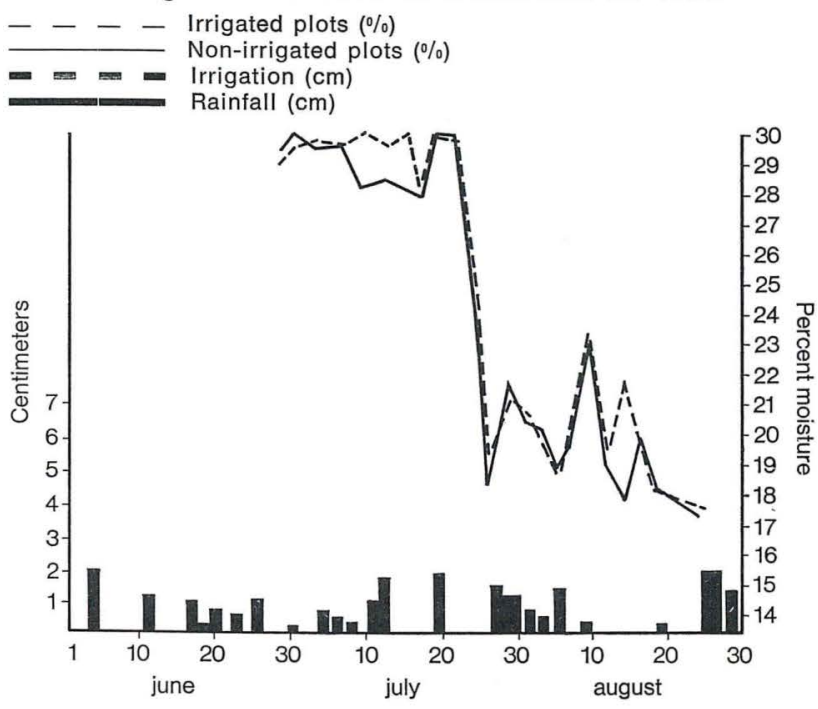

Figure 9. Bouyoucous moisture block readings taken at 10-centimeter depth measured in per cent moisture. Rainfall and irrigation measured in centimeters for 1966.

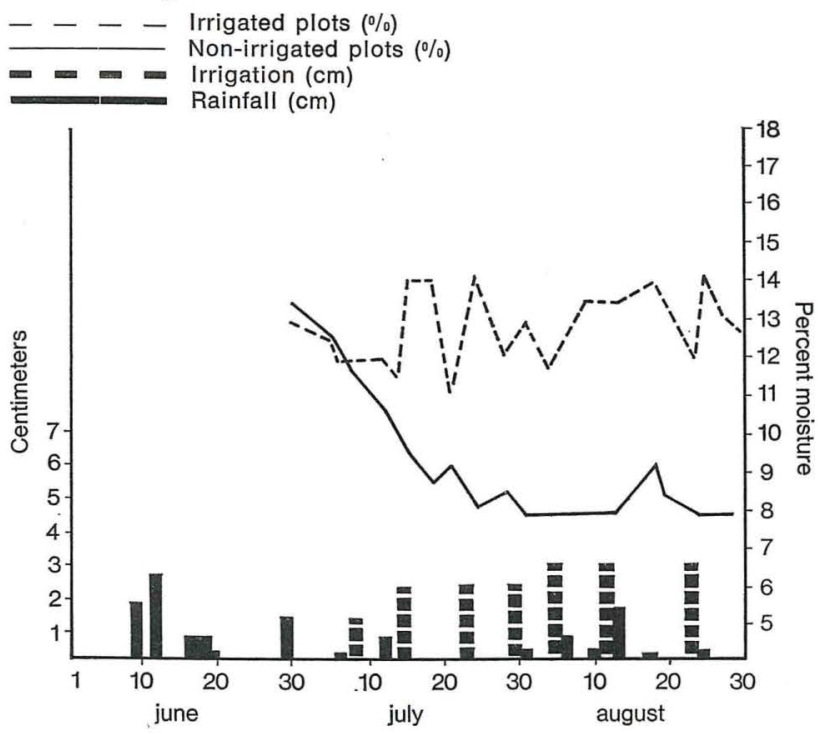


Figure 10. Bouyoucous moisture block readings taken at 20-centimeter depth measured in per cent moisture. Rainfall and irrigation measured in centimeters for 1966.

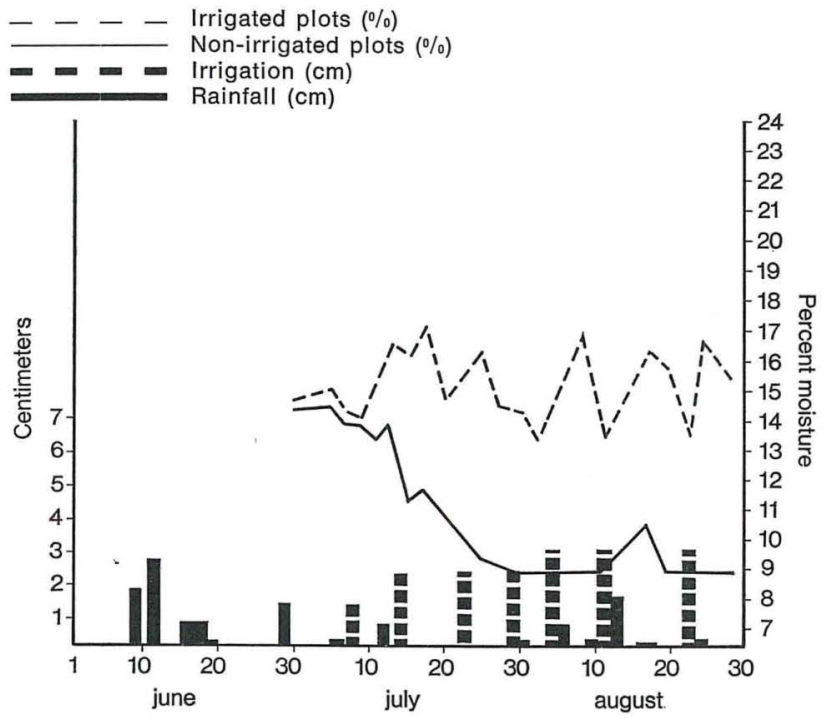

Figure 11. Bouyoucous moisture block readings taken at 30-centimeter depth measured in per cent moisture. Rainfall and irrigation measured in centimeters for 1966.
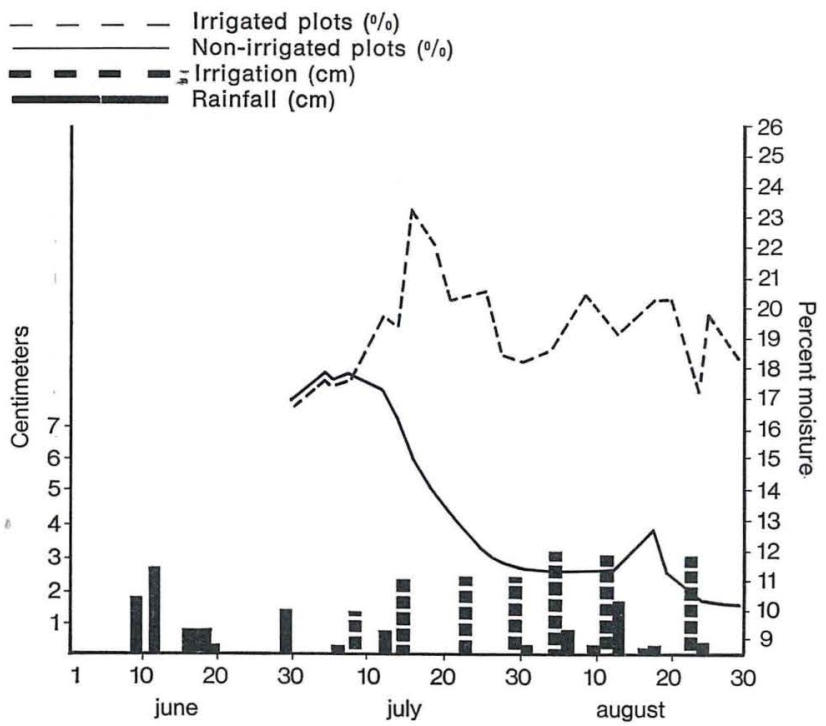

Figure 12. Bouyoucous moisture block readings taken at 50-centimeter depth measured in per cent moisture. Rainfall and irrigation measured in centimeters for 1966.

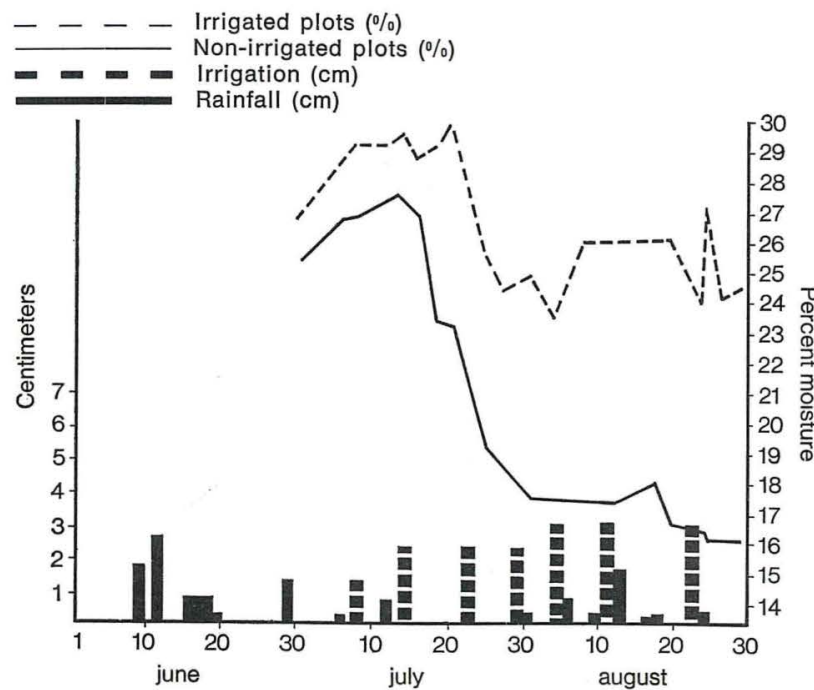

\section{Experimental Results}

Although this irrigation study was conducted from 1955 to 1967 , only the most important effects will be discussed. The data presented show the general trends of the entire study.

Rainfall records have been taken at Upper Marlboro for 56 years. The mean rainfall for the six-month period from April I to September 30 has been $590.3 \mathrm{~mm}$; but for the three months of June through August, it has been $320.5 \mathrm{~mm}$. July with $107.7 \mathrm{~mm}$ and August with $115.3 \mathrm{~mm}$ are slightly above the average of the other months. The mean monthly rainfall of $98.4 \mathrm{~mm}$ is considered an optimum amount for the growth of Maryland tobacco.

Table 1 presents the monthly totals for the period of this test. Totals range from II.7 to $426.7 \mathrm{~mm}$, a ratio of nearly 36 to 1 , while 3 -month totals range from 122.7 to $653.0 \mathrm{~mm}$, a ratio of more than 5 to 1 .

The summer of 1966 was the driest of the test period, with a rainfall of only $122.7 \mathrm{~mm}$. A total of $216 \mathrm{~mm}$ of supplemental irrigation was applied, adequate to maintain the soil in a favorable moisture condition, while in the unirrigated plots, there was almost no water for the plants.

The effect of irrigation in a very dry year is strikingly shown in Table 2. The overall difference in yield was $1018 \mathrm{~kg} / \mathrm{ha}$, the difference in price per kilo was US\$ 0.376 , and the difference in value per hectare was US\$ 1835 .

Higher levels of nitrogen fertilization increased yield, with irrigation, total value was not consistent, but the $134.5 \mathrm{~kg} / \mathrm{ha}$ nitrogen rate generally gave the highest total value. Unit value, an indicator of quality, decreased with increasing nitrogen rates. Without irrigation there were no differences in unit value, but because of the increased yield of the higher nitrogen rates, the highest rate produced the highest total value.

Wilson variety outyielded the Catterton variety, but, because of darker colors, had a lower unit value and consequently a lower total value.

Two experiments on plant population are reported in Table 3. In these tests, the rows were .9144 m apart,

Table 1. Rainfall in summer months at the University of Maryland Tobacco Experimental Farm, Upper Marlboro, Maryland, 1955 to 1967 inclusive.

\begin{tabular}{|c|c|c|c|c|}
\hline \multirow[b]{2}{*}{ Year } & \multicolumn{3}{|c|}{ Rainfall } & \multirow{2}{*}{$\begin{array}{c}\text { Total } \\
\mathrm{mm}\end{array}$} \\
\hline & $\begin{array}{c}\text { June } \\
\mathrm{mm}\end{array}$ & $\begin{array}{l}\text { July } \\
\text { mm }\end{array}$ & $\begin{array}{c}\text { August } \\
\mathrm{mm}\end{array}$ & \\
\hline 1955 & 110.7 & 115.6 & 426.7 & 653.0 \\
\hline 1956 & 104.1 & 179.6 & 57.7 & 341.4 \\
\hline 1957 & 121.7 & 19.0 & 79.5 & 220.2 \\
\hline 1958 & 81.8 & 264.7 & 177.0 & 523.5 \\
\hline 1959 & 106.4 & 154.7 & 94.7 & 355.8 \\
\hline 1960 & 32.8 & 109.7 & 160.5 & 303.0 \\
\hline 1961 & 99.6 & 109.0 & 66.0 & 274.6 \\
\hline 1962 & 130.0 & 79.0 & 17.0 & 226.0 \\
\hline 1963 & 223.3 & 31.7 & 76.7 & 331.7 \\
\hline 1964 & 65.8 & 86.4 & 44.4 & 196.6 \\
\hline 1965 & 69.9 & 92.5 & 44.2 & 206.6 \\
\hline 1966 & 80.0 & 11.7 & 30.7 & 122.7 \\
\hline 1967 & 32.8 & 101.6 & 188.0 & 322.4 \\
\hline Average & 96.8 & 104.2 & 112.6 & 313.6 \\
\hline
\end{tabular}


Table 2. Effects of irrigation, nitrogen rate and variety on yield, unit value and total value of Maryland tobacco in 1966.

\begin{tabular}{|c|c|c|c|c|c|}
\hline Variety & $\begin{array}{l}\text { Treatment } \\
\text { Irrigation }\end{array}$ & Nitrogen, kg/ha & $\begin{array}{l}\text { Yield } \\
\mathrm{kg} / \mathrm{ha}\end{array}$ & $\begin{array}{l}\text { Unit value } \\
\$ / \mathrm{kg}\end{array}$ & $\begin{array}{c}\text { Total value } \\
\$ / \text { ha }\end{array}$ \\
\hline Catterton & Irrigated & $\begin{array}{l}100.9 \\
134.5 \\
168.1\end{array}$ & $\begin{array}{l}1950 c * \\
2294 b \\
2388 a\end{array}$ & $\begin{array}{l}1.525 \mathrm{a} \\
1.457 \mathrm{~b} \\
1.380 \mathrm{c}\end{array}$ & $\begin{array}{l}2973 \mathrm{~b} \\
3343 \mathrm{a} \\
3296 \mathrm{a}\end{array}$ \\
\hline Catterton & Non-irrigated & $\begin{array}{l}100.9 \\
134.5 \\
168.1\end{array}$ & $\begin{array}{l}1252 \mathrm{~b} \\
1296 \mathrm{~b} \\
1444 \mathrm{a}\end{array}$ & $\begin{array}{l}0.933 \\
0.955 \\
0.943\end{array}$ & $\begin{array}{l}1156 \mathrm{~b} \\
1238 \mathrm{ab} \\
1361 \mathrm{a}\end{array}$ \\
\hline Wilson & Irrigated & $\begin{array}{l}100.9 \\
134.5 \\
168.1\end{array}$ & $\begin{array}{l}2431 b \\
2562 a \\
2608 a\end{array}$ & $\begin{array}{l}1.221 \mathrm{a} \\
1.201 \mathrm{a} \\
1.054 \mathrm{~b}\end{array}$ & $\begin{array}{l}2968 \mathrm{a} \\
3079 \mathrm{a} \\
2748 \mathrm{~b}\end{array}$ \\
\hline Wilson & Non-irrigated & $\begin{array}{l}100.9 \\
134.5 \\
168.1\end{array}$ & $\begin{array}{l}1259 c \\
1394 b \\
1487 a\end{array}$ & $\begin{array}{l}0.893 \\
0.893 \\
0.897\end{array}$ & $\begin{array}{l}1124 \mathrm{~b} \\
1245 \mathrm{ab} \\
1334 \mathrm{a}\end{array}$ \\
\hline \multicolumn{6}{|c|}{$\begin{array}{l}\text { Summary of variety effects, irrigation effects and nitrogen effects: } \\
\text { Variety }\end{array}$} \\
\hline $\begin{array}{l}\text { Catterton } \\
\text { Wilson }\end{array}$ & & & $\begin{array}{l}1771 \mathrm{~b} \\
1957 \mathrm{a}\end{array}$ & $\begin{array}{l}1.259 \mathrm{a} \\
1.064 \mathrm{~b}\end{array}$ & $\begin{array}{l}2229 a \\
2083 b\end{array}$ \\
\hline $\begin{array}{l}\text { Irrigation } \\
\text { Irrigated } \\
\text { Non-irrigated }\end{array}$ & & & $\begin{array}{l}2373 a \\
1355 b\end{array}$ & $\begin{array}{l}1.293 \mathrm{a} \\
0.917 \mathrm{~b}\end{array}$ & $\begin{array}{l}3069 a \\
1234 b\end{array}$ \\
\hline $\begin{array}{c}\text { Nitrogen, } \mathrm{kg} / \mathrm{ha} \\
100.9 \\
134.5 \\
168.1\end{array}$ & & & $\begin{array}{l}1723 \mathrm{c} \\
1886 \mathrm{~b} \\
1981 \mathrm{a}\end{array}$ & $\begin{array}{l}1.193 \mathrm{a} \\
1.180 \mathrm{a} \\
1.102 \mathrm{~b}\end{array}$ & $\begin{array}{l}2056 \mathrm{~b} \\
2226 \mathrm{a} \\
2184 \mathrm{ab}\end{array}$ \\
\hline
\end{tabular}
* In this table, and all mean tables hereafter, two means followed by the same letter are not significantly different at the $5 \%$ level. Means
not followed by the same letter are significantly different, and those with no letter were not subject to a mean separation because of the absence of significance in the analysis of variance (2).

the plants within the row were $.9144 \mathrm{~m}, .6096 \mathrm{~m}$, and $.4572 \mathrm{~m}$, resulting in populations of 11960,17939 , and 23919 plants per hectare. Gains in yield of $115 \mathrm{~kg} / \mathrm{ha}$ were obtained in 1957 from increasing plant populations from 11960 to 17939 plants per hectare, resulting in a gain of total value of US\$150 per hectare. In the I96I experiment, each of the two increments resulted in yield increases of over $100 \mathrm{~kg} / \mathrm{ha}$, and gains in total value of US $\$ 100$. In most other years, favorable responses to higher populations usually did not occur and about 18000 plants per hectare was adequate.

The study of the results for 1965, compared with 1964 and 1966, indicate that the omission of irrigation in 1965 led to depletion of soil moisture of sufficient magnitude to reduce yields and total return. A summary of agronomic results for 1964, 1965 and 1966 are presented in Table 4. It will be noted that the yield and total value for 1965 are lower than irrigated treatments for 1964 and 1966, but the unit value is

Table 3. Effect of plant population on yield, unit value and total value of Maryland tobacco.

\begin{tabular}{c|c|c|c|c}
\hline \multicolumn{2}{c|}{$\begin{array}{c}\text { Treatment } \\
\text { Year }\end{array}$} & $\begin{array}{c}\text { Yield } \\
\mathrm{kg} / \mathrm{ha}\end{array}$ & $\begin{array}{c}\text { Unit } \\
\text { value } \\
\$ / \mathrm{kg}\end{array}$ & $\begin{array}{c}\text { Total } \\
\text { value } \\
\$ / \mathrm{ha}\end{array}$ \\
\hline 1957 & 11960 & $1420 \mathrm{~b}$ & 1.086 & $1542 \mathrm{~b}$ \\
& 17939 & $1535 \mathrm{a}$ & 1.102 & $1692 \mathrm{a}$ \\
1961 & 11960 & $1532 \mathrm{~b}$ & 1.409 & $2158 \mathrm{~b}$ \\
& 17939 & $1638 \mathrm{ab}$ & 1.381 & $2262 \mathrm{ab}$ \\
& 23919 & $1741 \mathrm{a}$ & 1.358 & $2365 \mathrm{a}$ \\
\hline
\end{tabular}

the best. If the 1965 results are compared with nonirrigated treatments for the other two years, they are below I964 in yield and total value, and again not much different in unit value.

The high yields for both irrigated and unirrigated plots in 1964 may be attributed in part to the previous history of the area, as tall fescue had been grown for several years before 1964 on this field. Frequently, under Maryland conditions, yields are highest following a heavy sod. However the 1965 yields fall much below 1964, and the recovery in 1966 with irrigation was good in both yield and total value.

Table 4. Summary of effects of irrigation on yield, quality and value of Maryland tobacco in 1964, 1965, and 1966.

\begin{tabular}{l|l|l|c|c}
\hline \multicolumn{2}{c|}{ Treatment } & $\begin{array}{c}\text { Yield } \\
\mathrm{kg} / \mathrm{ha}\end{array}$ & $\begin{array}{c}\text { Unit } \\
\text { value } \\
\$ / \mathrm{kg}\end{array}$ & $\begin{array}{c}\text { Total } \\
\text { value } \\
\$ / \mathrm{ha}\end{array}$ \\
\hline 1964 & Irrigated & $2498 \mathrm{a}$ & 1.335 & 3336 \\
& Non-irrigated & $2327 \mathrm{~b}$ & 1.364 & 3175 \\
$1965^{*}$ & Irrigated & 2017 & 1.357 & 2738 \\
& Non-irrigated & 2017 & 1.357 & 2738 \\
1966 & Irrigated & $2373 \mathrm{a}$ & $1.293 \mathrm{a}$ & $3069 \mathrm{a}$ \\
& Non-irrigated & $1355 \mathrm{~b}$ & $0.917 \mathrm{~b}$ & $1234 \mathrm{~b}$ \\
\hline
\end{tabular}

* No irrigation was used in 1965.

\section{DISCUSSION OF RESULTS}

The response of Maryland tobacco to irrigation was predictable in most years, and was governed by the total amount of water available to the plants. This total included the available stored water, plus the 
recharge from natural rainfall and irrigation. Tobacco plants may pass through an early period of moisture stress, but this should not extend more than 30 days beyond transplanting (4). The desirability, or need, for this period of stress for Maryland tobacco has not been established.

The interrelationships between water supply, fertilizer treatment, plant population and variety are vital to the final product. Each factor will affect the outcome, but only within limits established by other factors. Thus plant population may have a peripheral bearing on the final result when other factors are near their optimal expression.

Both varieties used in the experiments represent the "old-line" Maryland tobacco which has evolved in over 300 years of continuous culture in the same area. Wilson variety yields more, but is highly sensitive to nitrogen level; Catterton variety can accept higher nitrogen fertilization without loss of quality.

There was evidence that the highest rate of nitrogen fertilization, $168.1 \mathrm{~kg} / \mathrm{ha}$, was detrimental to quality and consequently to total value. This is more apparent where water was not a limiting factor.

\section{SUMMARY}

Irrigation experiments on Maryland tobacco have been conducted since 1955 on Monmouth fine sandy loam, a typical tobacco soil of Southern Maryland. An overhead sprinkler system was employed. Moisture levels in the soil were studied, using Bouyoucous gypsum blocks and tensiometers. The following conclusions were made from this study:

1. In a year of severe drought, 1966, ample irrigation increased yields, unit value and total value. Irrigated yields were 175 per cent of non-irrigated; unit value was I4I per cent, and total value of irrigated tobacco was 247 per cent of non-irrigated.

2. Nitrogen fertilizer rates of $100.9,134.5$ and 168.1 $\mathrm{kg} / \mathrm{ha}$ were used. Under irrigation, gains in yield and total value, and some loss in unit value were obtained from the first added increment of fertilizer nitrogen above the base amount. Addition of the second increment produced smaller gains in yield, a greater loss in unit value, and losses in total value.

3. In the absence of irrigation, the supply of soil water could limit nitrogen assimilation by the plants. The higher rates of nitrogen fertilization were effective in increasing yield and total value over the lower increments. Even unit value was not adversely affected.

4. The Wilson broadleaf variety of Maryland tobacco consistently outyielded the Catterton medium broadleaf variety, but due to lower unit value, probably caused by darker colors, it had a lower total value.

5. Plant populations of about 18,000 per hectare produced increased yields and gross return over a population of about 12,000. Populations of 24,000 plants per hectare were excessive in most cases, and produced losses in yield and unit value.

6. Comparative response to irrigation depends on severity of drought, but late depletion of soil moisture levels may prevent the full potential development of the crop, and result in lower yields and total value.

\section{ZUSAMMENFASSUNG}

Seit 1955 wurden mit Maryland-Tabak auf feinem, sandigem Lehmboden (Monmouth), einem typischen Tabakboden von Süd-Maryland, unter Verwendung mechanischer Beregnungsanlagen Bewässerungsexperimente durchgeführt. Der Feuchtigkeitsgehalt des Bodens wurde mit Bouyoucous-Gipsblöcken und Tensiometern gemessen. Aus den Untersuchungen wurden folgende Schlußfolgerungen gezogen:

I. Im Jahre 1966, einem Jahr mit starker Trockenheit, führte reichliche Bewässerung zu einer Erhöhung der Erträge $(\mathrm{kg} / \mathrm{ha})$, ihres Wertes $(\$ / \mathrm{kg})$ und ihres Gesamtwertes $(\$ /$ ha). Im Vergleich zum Ertrag auf nicht bewässerten Böden stiegen die Erträge durch Bewässerung auf $175 \%$, ihr Wert auf $141 \%$ und ihr Gesamtwert auf $247 \%$.

2. Eine Stickstoffdüngung erfolgte mit 100,9 kg/ha, $134,5 \mathrm{~kg} / \mathrm{ha}$ und $168,1 \mathrm{~kg} / \mathrm{ha}$. Bei Bewässerung führte die erste über die Grundmenge hinausgehende Stickstoffgabe zu einer Steigerung des Ertrages und des Gesamtwertes und zu einer Verminderung des Wertes $(\$ / \mathrm{kg})$. Die zweite Steigerung der Düngung ergab geringere Zunahmen des Ertrages, eine größere Verminderung des Wertes $(\$ / \mathrm{kg})$ und Verringerungen des Gesamtwertes.

3. Wenn nicht bewässert wird, könnte die Stickstoffassimilation der Pflanzen durch den Wassermangel im Boden begrenzt werden. Im Vergleich zu den geringfügigen Steigerungen der Stickstoffdüngung bewirkten die höheren Stickstoffgaben eine Zunahme des Ertrages und des Gesamtwertes. Selbst der Wert je kg wurde nicht ungünstig beeinflußt.

4. Die Varietät Wilson-Broadleaf (Maryland) zeichnete sich im Vergleich zur Varietät Catterton-MediumBroadleaf regelmäßig durch höhere Erträge aus. Wegen ihres geringeren Wertes je $\mathrm{kg}$, der wahrscheinlich auf die dunklere Färbung zurückzuführen ist, hatten die Wilson-Tabake aber einen niedrigeren Gesamtwert.

5. Bei einem Bestand von 18000 Pflanzen je Hektar ergaben sich höhere Erträge und ein höherer Bruttogewinn als bei einem Pflanzenbestand von 12000 je Hektar. Die exzessive Steigerung auf 24000 Pflanzen je Hektar führte zu Verlusten an Ertrag und Wert je $\mathrm{kg}$.

6. Ein Vergleich der Reaktion auf künstliche Bewässerung hängt vom Ausmaß der Trockenheit $a b$; das späte Absinken des Grundwasserspiegels könnte die mögliche volle Entwicklung der Ernte jedoch verhindern und zu niedrigeren Erträgen und einem niedrigeren Gesamtwert ( $\$ /$ ha) führen.

\section{RESUME}

Des expériences d'irrigation par aspersion ont été faites depuis 1955 sur tabac Maryland en sol de limon sableux fin (sol de Monmouth), typique des cultures 
de tabac du Sud-Maryland. Le taux d'humidité du sol était mesuré au moyen de blocs de gypse Bouyoucous et de tensiomètres. Cette étude a fourni les résultats suivants:

1. En année très sèche, 1966, une irrigation abondante a accru les rendements (R), le prix moyen du $\mathrm{kg}$ (PM) et la valeur totale de la récolte (VT). Par rapport au témoin non irrigué, la récolte irriguée a eu un accroissement de $175 \%$ de $R$, de $141 \%$ de PM et de $247^{\circ} \%$ de VT.

2. En culture irriguée, on a comparé des doses (en $\mathrm{kg} / \mathrm{ha}$ ) de 100, 134 et 168 d'engrais azoté. Par rapport à la dose la plus basse, la dose moyenne a procuré un gain de $\mathrm{R}$ et de VT et une perte de PM; la dose la plus forte a procuré des accroissements plus faibles de $R$, une perte en PM et une perte en VT.

3. En l'absence d'irrigation, le taux d'humidité du sol pouvait limiter l'assimilation de l'azote par les plantes. Les doses supérieures de fertilisation azotée ont accru $\mathrm{R}$ et VT par rapport aux doses moindres; même PM n'a pas été influencé défavorablement.

4. Le tabac Maryland à grandes feuilles, var. Wilson, avait un rendement nettement supérieur à celui de la var. à feuilles moyennes Catterton, mais du fait d'un PM plus bas, probablement en raison d'une coloration plus foncée, il avait une VT plus basse.

5. Des densités de plantation d'environ 18000 plantes/ha donnaient des rendements et des revenus bruts supérieurs à une densité de 12000 plantes/ha. Des densités de 24000 plantes/ha étaient excessives dans la plupart des cas et provoquaient des pertes de $R$ et de PM.

6. L'effet de l'irrigation dépend de la sévérité de la sécheresse, mais un épuisement tardif de l'humidité du sol peut empêcher le plein développement potentiel de la culture et se traduire par des rendements et des valeurs totales de récoltes inférieurs.

\section{REFERENCES}

I. Bowling, J. D., McMurtrey, J. E., Jr., and Brown, D. E.: Variety description and performance tests with Maryland tobacco; Md. Agr. Expt. Sta. Bull. 1952, A 73 .

2. Duncan, D. B.: Multiple range and multiple tests; Biometrics IIV (1955) I-42.

3. Fieldhouse, D. J., and Palmer, W. C.: The climate of the northeast, Meteorological and agricultural drought; Del. Agr. Expt. Sta. Bull. 1965, 353.

4. McKee, C. G., Street, O. E., and Green, R. L.: Irrigation for Maryland tobacco; Md. Ext. Ser. Fact Sheet 166,1964 .

5. Richards, L. A.: Availability of water to crops on saline soils; U.S.D.A. Agr. Inf. Bull. 1959, 2 I0.

6. Slater, C. S., and Bryant, J. C.: Comparison of four methods of soil moisture measurement; Soil Sci. 61 (1946) 131-155.

7. Woltz, W. G., and Mason, D. D.: Effects of plant spacing and height of topping of bright tobacco on some agronomic characteristics; Proc. 4th World Tob. Sci. Congr. 1966, Athens, Greece.

\section{Physico-Chemical Properties*}

The chemical and physical properties of Maryland tobacco are quite different from other US cigarette tobaccos. Summaries of comparative composition have been presented by Garner et al. in 1934 (8) and Harlan and Moseley in 1955 (10). The results here presented in Table $I$ were obtained by the cooperative efforts of the laboratories of the leading tobacco companies, the State Agricultural Experiment Stations, and the Tobacco Division, Agricultural Research Service, United States Department of Agriculture. The Standards and Research Branch of the Tobacco Division, Agricultural Marketing Service, United States Department of Agriculture, supervised the collection and preparation of the samples, conducted many of the physical and chemical analyses, and collated and published the results.

Among the physical measurements, the weight in milligrams per square centimeter was a measure of bulk density. Both Burley and Maryland were lower in unit weight than flue-cured, hence had greater "filling capacity".

The moisture equilibrium data showed that flue-cured gained more moisture than Burley at relative humidities above $40 \%$. Burley, in turn, at $70 \%$ and $80 \%$ relative humidity, exceeded in moisture content the markedly "dry" Maryland. The absence of strongly hygroscopic constituents in Maryland tobacco is the basis for its excellent keeping quality and low shrinkage with ageing.

The chemical analyses were reported in groups of similar compounds. In the acid group, little difference can be noted, although flue-cured has been reported elsewhere, Harlan and Moseley (10), as being higher in total volatile acids and formic acid than the other two kinds.

Maryland and Burley were predictably low in reducing sugars. Maryland was higher in polyphenols, considerably higher in cellulose and crude fiber. These constituents affect its combustibility and smoke aroma. Unpublished studies show Maryland to have a low tensile strength, to be somewhat brittle and rather easily shattered.

Alkaloid contents were typical of the tobaccos of that era, but were high because of dry weather in those particular years. At present, nornicotine contents are lower, due to screening of breeding material to obtain the lowest possible content.

In the nitrogen data, the high content of total volatile bases in Burley might be noted. Much higher nitrate nitrogen contents in Burley have been reported by Broaddus et al. (5).

The wide difference in alcohol extracts is due mostly to the difference in content of alcohol-soluble reducing

\footnotetext{
* Presented at the 5th International Tobacco Scientific Congress, Hamburg, September 1970

Contribution No. 4353, Scientific Article No. A 1626, of the University of Maryland Agricultural Experiment Station, Department of Agronomy. Portions of these data were submitted by the senior author to the Graduate School, University of Maryland, in partial fulfillment of the requirements for the Master of Science degree.
} 
Table 1. Comparative analyses of United States cigarette tobaccos.*

\begin{tabular}{|c|c|c|c|c|}
\hline & & \multicolumn{3}{|c|}{$\begin{array}{c}\text { Content in } \% \text { of dry weight } \\
\text { by class }\end{array}$} \\
\hline & & $\begin{array}{c}\text { Flue- } \\
\text { cured } \\
1954 \\
\text { crop } \\
\end{array}$ & $\begin{array}{c}\text { Burley } \\
1952 \\
\text { crop }\end{array}$ & $\begin{array}{c}\text { Maryland } \\
1953 \\
\text { crop } \\
\end{array}$ \\
\hline \multicolumn{5}{|c|}{ Physical measurements } \\
\hline Sand & & 1.17 & 1.05 & 2.44 \\
\hline Weight, m & $\mathrm{g} / \mathrm{cm}^{2}$ & 7.1 & 5.0 & 4.7 \\
\hline \multicolumn{5}{|c|}{ Moisture equilibrium at $25^{\circ} \mathrm{C}$ : } \\
\hline $40 \% \mathrm{r}$ & elative humidity & 7.52 & 7.25 & 7.64 \\
\hline $60 \%$ & $" \quad " \quad$ & 12.14 & 9.57 & 9.89 \\
\hline $70 \%$ & $"$ & 15.67 & 12.39 & 11.01 \\
\hline $80 \%$ & $"$ & 20.20 & 16.64 & 12.21 \\
\hline \multicolumn{5}{|c|}{ Chemical constituents } \\
\hline \multicolumn{5}{|c|}{ Acids } \\
\hline Water s & soluble & 4.20 & 4.29 & 3.38 \\
\hline Total v & olatile acids & 0.161 & 0.125 & 0.177 \\
\hline Formic & acid & 0.026 & 0.012 & 0.013 \\
\hline $\mathrm{pH}$ & & 4.98 & 5.43 & 5.24 \\
\hline \multicolumn{5}{|c|}{ Carbohydrates } \\
\hline Reduci & ng sugars & 17.63 & 1.30 & 1.07 \\
\hline Polyph & enols & 1.75 & 0.415 & 2.87 \\
\hline Cellulo & & 7.04 & 10.21 & 12.44 \\
\hline Crude & fiber & 7.67 & 10.01 & 13.36 \\
\hline \multicolumn{5}{|c|}{ Alkaloids } \\
\hline Nicotin & & 3.31 & 4.26 & 2.36 \\
\hline Nornicc & tine & 0.15 & 0.26 & 0.11 \\
\hline Total a & Ikaloids & 3.46 & 4.52 & 2.47 \\
\hline \multicolumn{5}{|c|}{ Nitrogen compounds } \\
\hline Protein & & 0.83 & 1.59 & 1.32 \\
\hline Non-pr & otein N & 1.58 & 2.71 & 1.63 \\
\hline Total N & & 2.26 & 4.40 & 2.95 \\
\hline Nitrate & & - & 0.31 & 0.12 \\
\hline Alpha-a & $\operatorname{mino} \mathrm{N}$ & 0.204 & 0.519 & 0.311 \\
\hline Ammor & ia $\mathrm{N}$ & - & 0.223 & - \\
\hline Total volc & atile bases & 0.569 & 0.964 & 0.611 \\
\hline Petroleun & n ether extract & 9.44 & 7.21 & 6.71 \\
\hline Waxes & & 0.34 & 0.38 & 0.50 \\
\hline Alcohol e & xtract & 55.49 & 33.35 & 29.06 \\
\hline \multicolumn{5}{|l|}{ Ash } \\
\hline Soluble & ash & 4.31 & 6.39 & 7.38 \\
\hline Insolub & le ash & 8.13 & 13.02 & 10.05 \\
\hline Total a & & 12.44 & 19.41 & 17.43 \\
\hline Alkalini & ty of ash & 15.8 & 28.9 & 23.4 \\
\hline \multicolumn{5}{|c|}{ Inorganic constituents } \\
\hline Calciun & & 2.63 & 4.44 & 2.78 \\
\hline Magnes & sium & 0.356 & 0.774 & 0.567 \\
\hline Potassi & um & 1.97 & 3.38 & 3.54 \\
\hline Phosph & torus & 0.198 & 0.250 & 0.227 \\
\hline Mangar & nese & 0.025 & 0.039 & 0.060 \\
\hline Sulfur & & 0.56 & 0.76 & 1.11 \\
\hline Chlorin & & 0.90 & 0.48 & 0.26 \\
\hline
\end{tabular}

\footnotetext{
* These data and the methods of analyses are given in detail in the following publications: Flue-cured, U. S. D. A. Tech. Bull. No. 1225, 1960; Burley, U. S. D. A. Tech. Bull. No. 1186, 1958; and Chemical composition of representative grades of the 1953 and 1956 crops of Maryland tobacco, Con. Mar. Ser., Tob. Div. U. S. D. A
}

sugars in flue-cured, and their low content in the air-cured tobaccos.

The alkalinity of the ash of flue-cured tobacco was lower than that of Burley or Maryland, indicative of lower content of non-volatile organic acids, not here reported. Also, flue-cured was lower in total ash, and lower in all the ash constituents reported, except chlorine. If the values reported by Harlan and Moseley (10), of $0.774 \% \mathrm{Mg}$ in Burley, and $1.11 \% 5$ in Maryland, are used for the missing values in Table 1 , a better comparison can be made. Then, Burley has the highest contents of calcium, magnesium and phosphorus, and a potassium content nearly equal to Maryland. The "bluegrass" soils of Kentucky, derived from phosphatic limestones, influence the composition of the Burley tobacco grown there (7).

The content of chlorine of flue-cured tobacco is believed to be higher since these reports were compiled, due to widespread use of nematicides (14)

\section{Experimental Results}

The first article in this series presented the experimental conditions of these studies. Considerable portions of the data presented in Tables 2 through 9 of the present paper were obtained from tobacco grown in the irrigation studies. However, results from other studies of Maryland tobacco will also be used, indicated by appropriate citations and footnotes to the tables.

Analytical methods for nitrogen components were conventional. For the analysis of mineral elements, the authors are pleased to acknowledge the cooperation of Dr. A. V. Bandel and Mr. Carroll Stottiemeyer of the Department of Agronomy, University of Maryland, for the use of the Technicon Auto-Analyzer.

Differences in content of total alkaloids from irrigation were quite great, more than 50 per cent in 1966 . In 1957, an increased rate of irrigation caused a further decrease in alkaloids. Also in the varietal study, the effect of seasonal moisture levels overshadowed varietal differences. Here again, the 1966 crop grown without irrigation under extremely dry conditions had alkaloid contents over 4 per cent. In the other three years, with lesser rainfall deficits, the alkaloid contents averaged 2.22 per cent (3).

Increased rates of nitrogen fertilization resulted in increased levels of alkaloids in the leaf. This finding confirms many other experiments, such as reported by McMurtrey et al. (12). The Robinson variety of Maryland tobacco, noted for its demethylation of nicotine to nornicotine, was able to accumulate a greater amount of alkaloids, mostly as nornicotine, with increased nitrogen fertilization (Table 3).

Alkaloids accumulate as leaves mature, and this is apparent in the data related to stalk position. The lower middle leaves, or brights, have higher alkaloid contents than the less mature leaves higher on the stalk. Working with Connecticut Havanna Seed tobacco, Hanmer et al. (9) found more regular increase in alkaloid contents with height on the stalk. Heggestad and Bowman 
Table 2. Alkaloid content $(\%)$ of Maryland tobacco as affected by various treatments in several years.

\begin{tabular}{|c|c|c|c|c|c|c|c|c|c|}
\hline \multirow{2}{*}{ Treatment } & \multicolumn{9}{|c|}{ Years } \\
\hline & 1950 & $1953-54$ & 1957 & 1963 & 1964 & 1965 & 1966 & 1967 & Ave. \\
\hline \multicolumn{10}{|l|}{ Irrigation } \\
\hline Irrigated & & & 2.45 & 2.44 & 2.47 & & 1.68 & & 2.26 \\
\hline Non-irrigated & & & 3.54 & 2.93 & 2.67 & & 3.52 & & 3.17 \\
\hline \multicolumn{10}{|l|}{ Variety (3) } \\
\hline Catterton & & & & & 2.81 & 1.77 & 4.16 & 2.46 & 2.80 \\
\hline Wilson & & & & & 2.59 & 1.70 & 3.86 & 2.37 & 2.63 \\
\hline \multicolumn{10}{|l|}{ Nitrogen rate, $\mathrm{kg} / \mathrm{ha}$} \\
\hline 33.6 & 1.46 & & & & & & & & \\
\hline 89.7 & 2.01 & & & & & & & & \\
\hline 44.8 & & & 2.55 & & & & & & \\
\hline 62.8 & & & 3.07 & & & & & & \\
\hline 100.9 & & & & & 2.05 & & & & \\
\hline 134.5 & & & & & 2.72 & & & & \\
\hline 168.1 & & & & & 2.94 & & & & \\
\hline \multicolumn{10}{|l|}{ Plant population } \\
\hline 11960 plants/ha & & & 2.85 & & & & & & \\
\hline 17939 plants/ha & & & 2.78 & & & & & & \\
\hline \multicolumn{10}{|l|}{ Stalk position $(6,13)$} \\
\hline Seconds (bottom) & 2.09 & 2.80 & & & & & 2.68 & & 2.52 \\
\hline Brights (lower middle) & 2.90 & 3.13 & & & & & 3.02 & & 3.02 \\
\hline Dull bri. (upper middle) & 3.29 & 2.79 & & & & & 2.28 & & 2.77 \\
\hline Dull (top) & 2.84 & 2.52 & & & & & 2.43 & & 2.60 \\
\hline
\end{tabular}

Table 3. Degree of alkaloid conversion with Robinson variety at two nitrogen rates, 1950 (6).

\begin{tabular}{c|c|c|c|c}
\hline $\begin{array}{c}\text { Nitrogen rate } \\
\mathrm{kg} / \mathrm{ha}\end{array}$ & \% Nicotine & $\%$ Nornicotine & $\%$ Total alkaloids & $\begin{array}{c}\text { Ratio of nicotine } \\
\text { to total alkaloids }\end{array}$ \\
\hline 33.6 & .035 & .473 & .508 & .07 \\
89.7 & .355 & 2.430 & 2.785 & .13 \\
\hline
\end{tabular}

Table 4. Total nitrogen content $(\%)$ of Maryland tobacco as affected by various treatments in several years.

\begin{tabular}{|c|c|c|c|c|c|c|}
\hline \multirow{2}{*}{ Treatment } & \multicolumn{6}{|c|}{ Years } \\
\hline & 1963 & 1964 & 1965 & 1966 & 1967 & Ave. \\
\hline \multicolumn{7}{|l|}{ Irrigation } \\
\hline Irrigated & 2.40 & 3.02 & & 2.37 & & 2.60 \\
\hline Non-irrigated & 2.53 & 3.15 & & 2.62 & & 2.77 \\
\hline \multicolumn{7}{|l|}{ Variety (3) } \\
\hline Catterton & & 2.47 & 2.33 & 3.11 & 2.59 & 2.62 \\
\hline Wilson & & 2.82 & 2.30 & 3.54 & 2.69 & 2.84 \\
\hline \multicolumn{7}{|l|}{ Nitrogen rate } \\
\hline $100.9 \mathrm{~kg} / \mathrm{ha}$ & & 2.79 & & & & \\
\hline $134.5 \mathrm{~kg} / \mathrm{ha}$ & & 3.16 & & & & \\
\hline $168.1 \mathrm{~kg} / \mathrm{ha}$ & & 3.25 & & & & \\
\hline
\end{tabular}

Table 5. Total nitrogen content and insoluble nitrogen content $(\%)$ of Maryland tobacco as affected by stalk position in several years.

\begin{tabular}{|c|c|c|c|c|c|c|c|}
\hline \multirow{2}{*}{ Stalk position } & \multicolumn{3}{|c|}{ Total nitrogen } & \multicolumn{3}{|c|}{ Insoluble nitrogen } & \multirow{2}{*}{$\begin{array}{l}\text { Ratio average } \\
\text { Ins. } \mathrm{N} / \text { Total } \mathrm{N}\end{array}$} \\
\hline & $1952^{*}$ & $|1953-54(13)|$ & Ave. & 1952 & $1953-54$ & Ave. & \\
\hline Seconds (bottom) & 1.22 & 1.75 & 1.49 & 1.01 & .85 & .93 & .62 \\
\hline Brights (lower middle) & 1.39 & 2.28 & 1.84 & 1.11 & 1.05 & 1.08 & .59 \\
\hline Dull bri. (upper middle) & 1.70 & 3.22 & 2.46 & 1.02 & 1.50 & 1.26 & .51 \\
\hline Dull (top) & 2.44 & 3.96 & 3.20 & 1.19 & 1.85 & 1.52 & .48 \\
\hline
\end{tabular}

" Data for 1952 from De Hondt, H. A., 1955: The effect of phosphorus rates for Maryland tobacco on the content of nitrogen fractions in the plant, Dissert. Abstr., 1955, 15. 
Table 6. Nitrate nitrogen content $(\%)$ of Maryland tobacco as affected by nitrogen rate and stalk position in 1966 and 1967.

\begin{tabular}{l|ll|l}
\hline & \multicolumn{2}{|c|}{ Years } & \multirow{2}{*}{ Ave. } \\
& 1966 & 1967 & \\
\hline Nitrogen rate & & & \\
$100.9 \mathrm{~kg} / \mathrm{ha}$ & .057 & .128 & .093 \\
$134.5 \mathrm{~kg} / \mathrm{ha}$ & .087 & .225 & .156 \\
$168.1 \mathrm{~kg} / \mathrm{ha}$ & .080 & .390 & .235 \\
Position on stalk & & & \\
Seconds (bottom) & .106 & .354 & .230 \\
Brights (lower middle) & .077 & .185 & .131 \\
Dull bri. (upper middle) & .051 & .270 & .161 \\
Dulls (top) & .067 & .182 & .125 \\
\hline
\end{tabular}

(II) found that alkaloids accumulated with delayed harvest of Burley tobacco.

Contents of total nitrogen and insoluble nitrogen are shown in Tables 4 and 5 . The differences from irrigation were not large. With irrigation, total nitrogen utilization can be higher because of increases in yield, even though percentages are lowered by a dilution effect.

While Wilson had a higher nitrogen content than Catterton in three years out of four, the difference was statistically significant only in 1964 .

Higher nitrogen rates increased total nitrogen content of the leaf only slightly. This again is possibly because of the dilution effect with increased yields.

There was a regular increase in content of total nitrogen from the bottom to the top of the stalk. Insoluble nitrogen increased more slowly, and was present in a lower ratio to total nitrogen, from bottom to top of the plant. The lower ratio in the upper leaves was indicative of lesser maturity of these leaves when the plants were harvested by stalk cutting.

Table 6 shows the nitrate nitrogen content of the cured leaves for the 1966 and 1967 crop years. In 1966, despite drought conditions, nitrates were not accumulated to any marked degree; while in 1967, rather large contents were present. The relationship of leaf nitrate

Figure 1. Bouyoucous moisture block readings taken at 4-inch depth measured in per cent moisture. Rainfall and irrigation measured in centimeters for 1967.
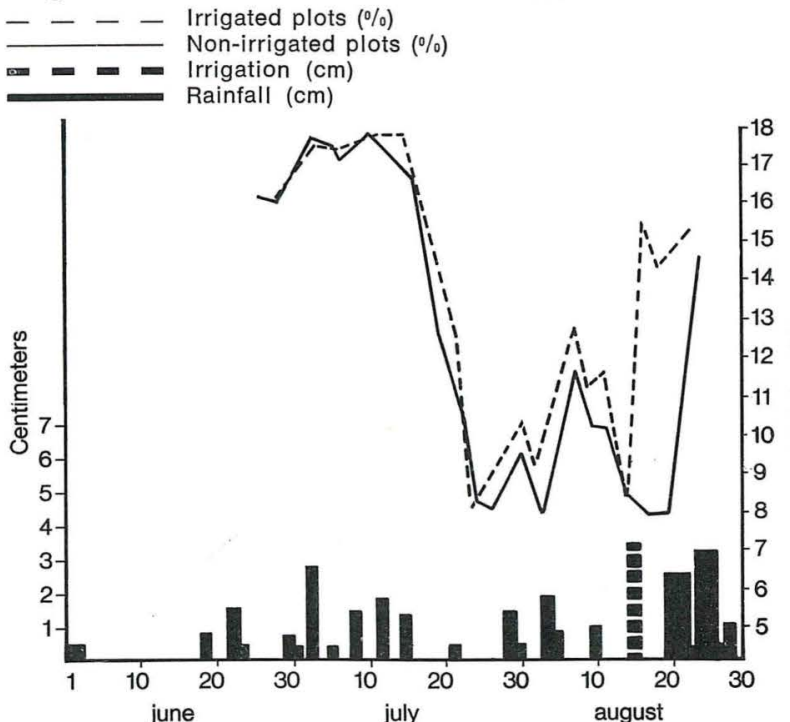

content to rate of nitrogen fertilization was clearly shown in 1967, but was not apparent in 1966.

The effect of leaf position on the stalk showed that the greatest accumulation of nitrate nitrogen occurred in the overripe leaves at the base of the plant. The relative contents of the other three groups were not consistent in the two years, as the dull brights were lowest in 1966 and highest in 1967.

The soil moisture levels for 1967, Figures 1-4, partially can be used to explain the leaf nitrate levels for that year. Only one irrigation was employed, following four weeks of dry weather which greatly depleted the soil moisture. The heavy rains of late August followed soon after, and soil nitrate production and plant growth were greatly stimulated. Harvest found the plants still gorged with large amounts of unconverted nitrate nitrogen. As a result, the cured leaves had a greenish color which adversely affected quality and price. No agronomic benefits attributable to the single late irrigation were found.

Figure 2. Bouyoucous moisture block readings taken at 8-inch depth measured in per cent moisture. Rainfall and irrigation measured in centimeters for 1967.

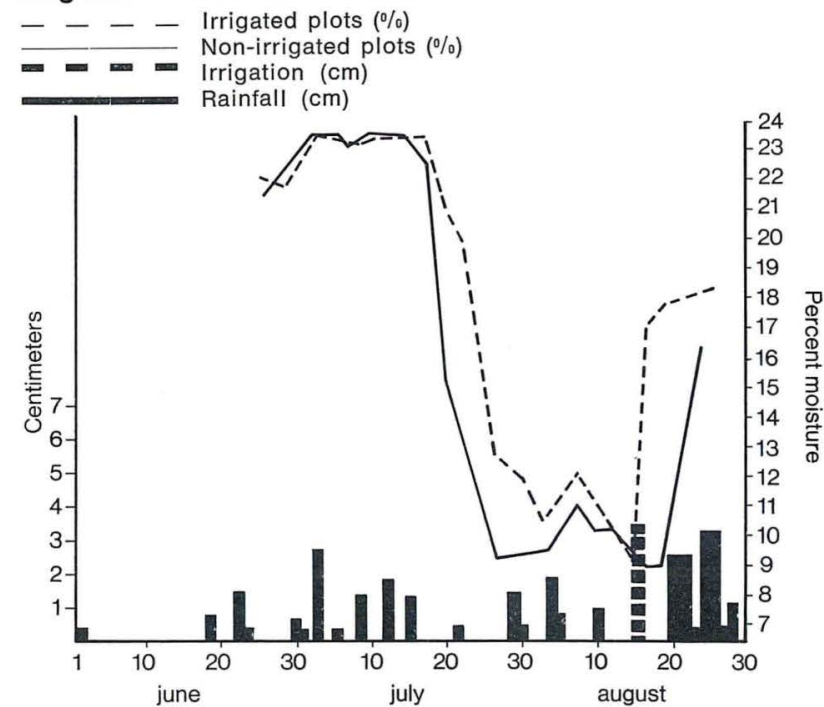

Figure 3. Bouyoucous moisture block readings taken at 12-inch depth measured in per cent moisture. Rainfall and irrigation measured in centimeters for 1967.

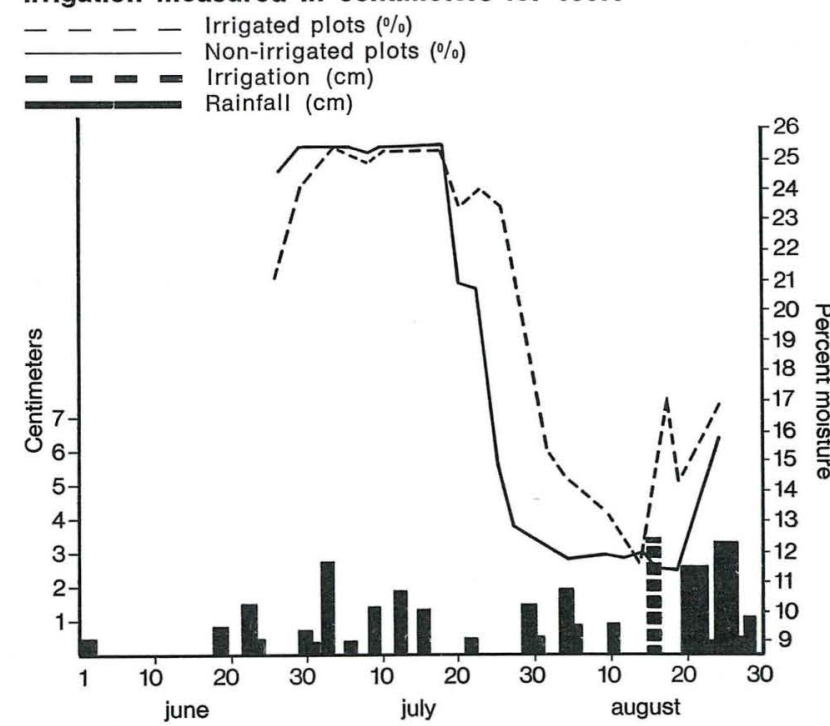


Figure 4. Bouyoucous moisture block readings taken at 20-inch depth measured in per cent moisture. Rainfall and irrigation measured in centimeters for 1967.

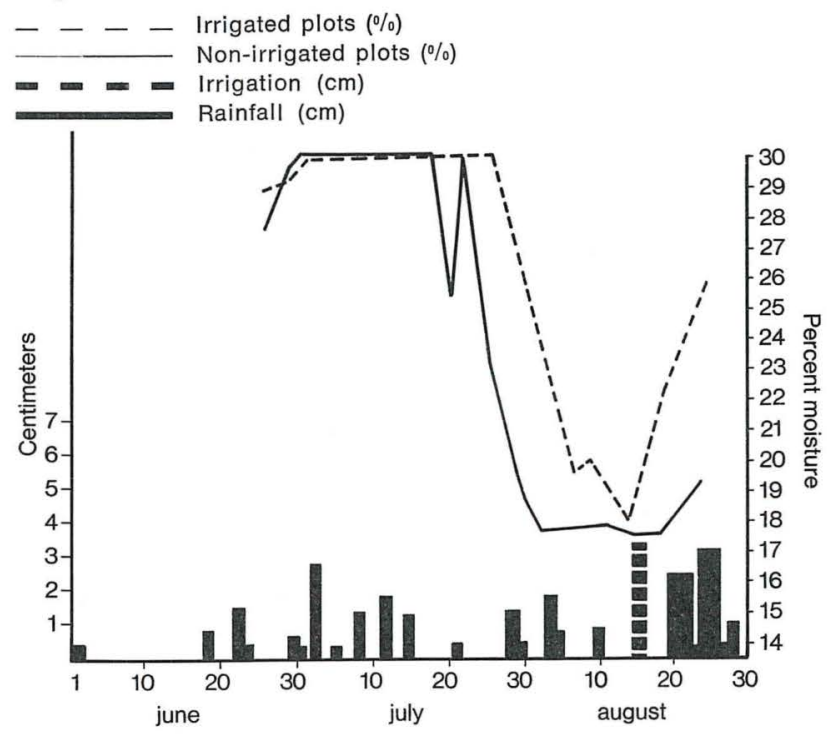

Analyses of the mineral composition of the 1966 crop, as presented in Table 7 , show that irrigation resulted in increases in phosphorus, potassium, and calcium, but not in magnesium. The relatively high solubility of magnesium compounds may have permitted their leaching under irrigation.

Wilson contained considerably more potassium than Catterton, otherwise was very similar in mineral composition.

Stalk position influenced mineral composition rather markedly, with phosphorus increasing from bottom to top, calcium and magnesium decreasing, and potassium showing no clear trend. The results resemble those obtained by Hanmer et al. (9).

The rate of nitrogen fertilization had no consistent effect on mineral composition.

Table 7. Mineral composition of Maryland tobacco as affected by irrigation, variety, stalk position and rate of nitrogen fertilization, 1966.

\begin{tabular}{|c|c|c|c|c|}
\hline & \multicolumn{4}{|c|}{$\begin{array}{c}\text { Mineral content } \\
\% \text { dry weight of the cured leaf }\end{array}$} \\
\hline & $\mathrm{P}$ & K & $\mathrm{Ca}$ & $\mathrm{Mg}$ \\
\hline \multicolumn{5}{|l|}{ Irrigation } \\
\hline Irrigated & .173 & 4.42 & 3.20 & 1.20 \\
\hline Non-irrigated & .152 & 3.09 & 2.84 & 1.29 \\
\hline \multicolumn{5}{|l|}{ Variety } \\
\hline Wilson & .168 & 4.15 & 3.00 & 1.30 \\
\hline Catterton & .157 & 3.35 & 3.04 & 1.19 \\
\hline \multicolumn{5}{|l|}{ Stalk position } \\
\hline Seconds (bottom) & .119 & 3.30 & 3.73 & 1.52 \\
\hline Brights & .141 & 3.73 & 3.28 & 1.29 \\
\hline Dull brights & .186 & 4.10 & 2.64 & 1.15 \\
\hline Dulls (top) & .204 & 3.94 & 2.44 & 1.01 \\
\hline \multicolumn{5}{|c|}{ Nitrogen fertilization, $\mathrm{kg} / \mathrm{ha}$} \\
\hline 100.9 & .165 & 3.80 & 3.00 & 1.32 \\
\hline 134.5 & .161 & 3.72 & 3.03 & 1.19 \\
\hline 168.1 & .160 & 3.81 & 3.09 & 1.27 \\
\hline
\end{tabular}

\section{Physical Properties}

Fire-holding capacity, as measured by duration of burn, has an important bearing on the value of cigarette tobacco. The "free-burning" quality of Maryland tobacco, plus its aroma, is the basis for its use as the main component of Swiss "Maryland" cigarettes. The use of any additives except water is forbidden to the Swiss cigarette manufacturers, hence the need for a naturally good burning tobacco. Formerly Maryland tobacco was used in US cigarettes for the same purpose.

The elastic quality of the better grades of cured Maryland tobacco is related to the cellular structure. During the latter stages of growth of the leaf, the epidermal cells continue to enlarge, whereas the parenchyma cell walls have lost their elasticity, and are ruptured and torn. A marked degree of disorganization occurs in the mesophyll, and numerous air spaces are found, which provide an adequate oxygen supply for combustion. The high contents of potassium, cellulose and crude fiber and low content of chlorine are also beneficial to burn. Bowling (4) has shown that an adequate supply of calcium and magnesium, as well as potassium, improves burn, that carbonate sources of these cations are superior to sulfates, and that an excess supply of phosphate is detrimental to burn.

While the data on burn of the 1966 irrigation studies was not statistically significant, the burn of wet-weather crops is usually better than of dry.

Increased levels of nitrogen fertilization was shown to improve burn (Table 8). Anderson et al. (I) showed improved burn from nitrogen rates as high as $336.2 \mathrm{~kg} /$ ha of $\mathrm{N}$.

The markedly superior burn of the leaves from near the base of the plant was probably because of their more open structure, but as shown in Table 7 , they were also higher in calcium and magnesium, and lower in phosphorus, than the upper leaves, while potassium content was nearly equal.

No varietal difference in fire-holding capacity between Catterton and Wilson was found in any year.

Table 9 presents some data on filling capacity, or specific volume, for the variety trials reported by

Table 8. Fire-holding capacity (burn in seconds) of Maryland tobacco as affected by various treatments in several years.

\begin{tabular}{|c|c|c|c|c|c|}
\hline \multirow{2}{*}{ Treatments } & \multicolumn{4}{|c|}{ Years } & \multirow{2}{*}{ Ave. } \\
\hline & 1964 & 1965 & 1966 & $\mid 1967$ & \\
\hline \multicolumn{6}{|l|}{ Variety (3) } \\
\hline Catterton & 3.2 & 5.4 & 3.3 & 7.0 & 4.7 \\
\hline Wilson & 4.2 & 5.0 & 3.5 & 6.5 & 4.8 \\
\hline \multicolumn{6}{|l|}{ Nitrogen rate } \\
\hline $100.9 \mathrm{~kg} / \mathrm{ha}$ & & & & 3.80 & \\
\hline $134.5 \mathrm{~kg} / \mathrm{ha}$ & & & & 5.65 & \\
\hline $168.1 \mathrm{~kg} / \mathrm{ha}$ & & & & 5.91 & \\
\hline \multicolumn{6}{|l|}{ Position on stalk } \\
\hline Seconds (bottom) & & & & 8.24 & \\
\hline Brights (lower middle) & & & & 6.58 & \\
\hline Dull bri. (upper middle) & & & & 3.12 & \\
\hline Dulls (top) & & & & 2.47 & \\
\hline
\end{tabular}


Table 9. Filling capacity (c. c./gm) of Maryland tobacco as affected by various treatments in several years.

\begin{tabular}{|c|c|c|c|c|c|c|}
\hline \multirow{2}{*}{ Treatments } & \multicolumn{4}{|c|}{ Years } & \multirow{2}{*}{ Ave. } & \multirow{2}{*}{$1966^{*}$} \\
\hline & 1964 & 1965 & 1966 & 1967 & & \\
\hline \multicolumn{7}{|l|}{ Variety (3) } \\
\hline Catterton & 4.99 & 6.66 & 4.69 & 6.65 & 5.75 & 5.79 \\
\hline Wilson & 4.76 & 6.44 & 4.03 & 6.42 & 5.41 & 5.58 \\
\hline \multicolumn{7}{|l|}{ Irrigation } \\
\hline Irrigated & & & 6.12 & & & \\
\hline Non-irrigated & & & 5.03 & & & \\
\hline \multicolumn{7}{|l|}{ Nitrogen rate } \\
\hline $100.9 \mathrm{~kg} / \mathrm{ha}$ & & & 5.91 & & & \\
\hline $134.5 \mathrm{~kg} / \mathrm{ha}$ & & & 5.80 & & & \\
\hline $168.1 \mathrm{~kg} / \mathrm{ha}$ & & & 5.67 & & & \\
\hline
\end{tabular}

* From irrigation studies of 1966.

Aycock et al. (3) and also for the 1966 irrigation studies, the differences due to variety, nitrogen rate and irrigation treatment. The method of Artho et al. (2) was used under closely controlled conditions of temperature and relative humidity.

In these trials, Catterton had a small but consistently higher specific volume than did Wilson, but was only statistically significant in one case.

The use of supplemental irrigation increased the specific volume to a marked degree. However, higher rates of nitrogen fertilization caused some decrease in filling capacity.

From data presented by Artho et al. (2) in the second part of their study, it would seem that flue-cured and Burley had lower specific volume measurements than Maryland.

\section{SUMMARY}

1. Results of a cooperative study on the composition of US cigarette tobaccos are summarized. Maryland tobacco was highest in cellulose and crude fiber, was least hygroscopic, had lowest volume weight. Alkaloids were low, total $\mathrm{N}$, alpha-amino $\mathrm{N}$ and total volatile bases intermediate. Soluble and total ash, and alkalinity of ash were high, as were potassium, magnesium and manganese. Calcium and phosphorus were intermediate, chlorine low.

2. Under experimental conditions, total alkaloid content was lowered by irrigation and increased by higher nitrogen fertilization. The Robinson variety was notably high in nornicotine. Catterton and Wilson varieties were similar in alkaloid content. The highest alkaloids were found in most mature leaves from the middle of the stalk.

3. Total nitrogen content was not greatly reduced by irrigation, nor increased by higher nitrogen rates. Variety effect was small. Nitrogen content increased regularly from bottom to top of plant.

4. Nitrate nitrogen contents were high in 1967, when late rains caused renewed growth, but were lower in 1966 when drought continued to harvest time.
5. Irrigation led to increased uptake of phosphorus, potassium and calcium, but not magnesium. Wilson contained more potassium than Catterton. Phosphorus was highest in upper leaves, calcium and magnesium highest in lower leaves, potassium was not consistent. Rate of nitrogen fertilization did not affect mineral composition.

6. Duration of burn was not affected by variety. Increased nitrogen fertilization improved burn. Irrigation had no significant effect, contrary to expectations. The lower leaves burned longer than the upper leaves of the plant.

7. Filling capacity, or specific volume, was higher in irrigated tobacco, it decreased with increased nitrogen fertilization. Catterton had slightly higher filling capacity than Wilson.

\section{ZUSAMMENFASSUNG}

I. Die Ergebnisse einer Gemeinschaftsuntersuchung der Zusammensetzung amerikanischer Cigarettentabake werden dargelegt. Maryland-Tabak hatte den höchsten Gehalt an Cellulose und Rohfaser, war am wenigsten hygroskopisch und hatte das geringste Volumengewicht. Sein Gehalt an Alkaloiden war niedrig, für Gesamtstickstoff, Alpha-amino-Stickstoff und Gesamte Flüchtige Basen ergaben sich mittlere Werte. Der Gehalt an löslicher und gesamter Asche, die Alkalität der Asche sowie der Gehalt an Kalium, Magnesium und Mangan waren hoch. Für Calcium und Phosphor fanden sich mittlere Gehalte, die Chlorwerte lagen niedrig.

2. Unter experimentellen Bedingungen wurde der Gehalt an Gesamtalkaloiden durch künstliche Bewässerung vermindert und durch stärkere Stickstoffdüngung erhöht. Die Tabakvarietät Robinson hatte einen bemerkenswert hohen Gehalt an Nornikotin. Der Alkaloidgehalt der Varietäten Catterton und Wilson war nahezu gleich. Der höchste Alkaloidgehalt wurde in den reifsten Blättern von der Mitte des Stengels festgestellt.

3. Der Gehalt an Gesamtstickstoff wurde weder durch Bewässerung beträchtlich vermindert noch durch höhere Stickstoffgaben erhöht. Die Unterschiede zwischen den Varietäten waren gering. In der Pflanze nahm der Gehalt an Stickstoff von unten nach oben zu.

4. Im Jahre 1967, in dem späte Regenfälle prolongiertes Wachstum verursachten, war der Nitratstickstoffgehalt der Tabake hoch. Im Jahre 1966, in dem die Trockenheit bis zur Erntezeit anhielt, war er vermindert.

5. Künstliche Bewässerung führte $\mathrm{zu}$ einer erhöhten Aufnahme von Phosphor, Kalium und Calcium, nicht aber von Magnesium. Die Varietät Wilson enthielt mehr Kalium als die Varietät Catterton. Der Phosphorgehalt war in den oberen Blättern am höchsten, der Gehalt an Calcium und Magnesium in den unteren. Für den Gehalt an Kalium ließ sich eine derartige Abhängigkeit nicht feststellen. Die Dosierung der Stickstoffdüngung beeinflußte das Verhältnis zwischen den Gehalten an den einzelnen Mineralien nicht. 
6. Die Glimmgeschwindigkeit zeigte keine Abhängigkeit von der Tabakvarietät. Erhöhte Stickstoffdüngung verbesserte die Glimmfähigkeit. Die künstliche Bewässerung hatte entgegen den Erwartungen keinen signifikanten. Einfluß. Die unteren Blätter der Pflanze verglimmten langsamer als die oberen.

7. Die Füllfähigkeit nahm nach künstlicher Bewässerung $z u$, mit zunehmender Stickstoffdüngung nahm sie ab. Tabake der Varietät Catterton zeigten eine etwas höhere Füllfähigkeit als Tabake der Varietät Wilson.

\section{RESUME}

I. On présente un résumé des résultats obtenus au cours d'un travail en commun sur la composition des tabacs à cigarettes américains. Le tabac du Maryland possédait la teneur la plus élevée en cellulose et en fibre brute; il était le moins hygroscopique et avait le plus petit poids volumique. La teneur en alcaloïdes était basse, la teneur en $\mathrm{N}$ total, en $\mathrm{N} \alpha-$ aminé et en bases volatiles totales était moyenne. Le taux de cendre soluble et totale, et l'alcalinité de la cendre étaient élevés, de même que les taux de $\mathrm{K}, \mathrm{Mg}$ et $\mathrm{Mn}$. Les teneurs en $\mathrm{Ca}$ et en $\mathrm{P}$ étaient moyennes, la teneur en $\mathrm{Cl}$ était basse.

2. Dans les conditions des expériences, la teneur en alcaloïdes totaux fut diminuée par l'irrigation, et augmentée par une fertilisation azotée accrue. La variété Robinson était remarquablement riche en nornicotine. Les variétés Catterton et Wilson avaient des teneurs similaires en alcaloïdes. Les feuilles médianes les plus mûres étaient les plus riches en alcaloïdes.

3. Le taux de $\mathrm{N}$ total ne fut pas sensiblement réduit par l'irrigation, ni augmenté par des apports plus élevés d'azote. D'une variété à l'autre, les différences étaient minimes. La teneur en $\mathrm{N}$ augmentait régulièrement à partir du bas jusqu'au sommet de la plante.

4. Les teneurs en $\mathrm{N}$ nitrique furent élevées en 1967 , lorsque des pluies tardives provoqèrent une nouvelle croissance, mais furent plus basses en 1966, lorsque la sécheresse dura jusqu'à la récolte.

5. L'irrigation provoqua une absorption accrue de $P$, $\mathrm{K}$ et $\mathrm{Ca}$, mais non de $\mathrm{Mg}$. La variété Wilson contenait plus de $\mathrm{K}$ que la variété Catterton. Le taux de $P$ était le plus élevé dans les feuilles hautes, celui de Ca et de $\mathrm{Mg}$ était le plus élevé dans les feuilles basses, celui de $\mathrm{K}$ était variable. Le degré de fertilisation azotée n'affecta pas la composition minérale.

6. La durée de combustion ne dépendait pas de la variété. Une fertilisation azotée accrue améliorait la combustibilité. L'irrigation n'avait aucun effet significatif, contrairement aux prévisions. Les feuilles inférieures avaient une durée de combustion plus longue que les feuilles supérieures.

7. Le pouvoir de remplissage, ou volume spécifique, était plus grand pour le tabac irrigué; il diminuait en fonction de l'augmentation de la fertilisation azotée. La var. Catterton avait un pouvoir de remplissage légèrement plus élevé que la var. Wilson.

\section{REFERENCES}

I. Anderson, P. J., Swanback, T. R., and Street, O. E.: Quantity of fertilizer nitrogen required for an acre of tobacco; Conn. Agr. Exp. Sta. Bull. 1938, 410.

2. Artho, A. J., Marshall, H. V., and Weybrew, J. A.: Physical characteristics of cured tobacco, I. Simplified procedures for measuring specific volume and fragility, Tob. Sci. 7 (1963) 191-197; II. Some factors affecting certain physical properties, Tob. Sci. 7 (1963) 198-202.

3. Aycock, M. K., Jr., McKee, C. G., Hoyert, J. H., Street, O. E., and Byrd, B. W., Jr.: Performance of Maryland tobacco varieties and breeding lines, 1964-1967; Md. Agr. Exp. Sta. Misc. Pub. 1968, 682.

4. Bowling, J. D.: Phosphorus, potassium, calcium and magnesium requirements of Maryland tobacco grown on Monmouth soil; Md. Agr. Exp. Sta. Bull. I967, A-I5I.

5. Broaddus, G. M., York, J. E., Jr., and Moseley, J. M.: Factors affecting the level of nitrate nitrogen in cured tobacco leaves; Tob. Sci. 9 (1965) 149-157.

6. Engle, H. B., McMurtrey, J. E., Jr., and Brown, D. E.: Maryland tobacco - An evaluation of field cultural practices and their interactions; Md. Agr. Exp. Sta. Bull. 1960, A-110.

7. Garner, W. W.: The production of tobacco, Rev., Ist Ed. Blakiston, New York, 1951.

8. Garner, W. W., Bacon, C. W., and Bowling, J. D.: Cigarette and cigar tobaccos - Relationship of production conditions to chemical and physical characteristics; Ind. Eng. Chem., Ind. Edn., 26 (1934) 970-974.

9. Hanmer, H. R., Street, O. E., and Anderson, P. J.: Variation in chemical composition of cured tobacco leaves according to position on stalk; Conn. Agr. Exp. Sta. Bull. 433: 177-186, 1940.

10. Harlan, W. R., and Moseley, J. M.: Tobacco - In Encyclopedia of Chemistry and Technology; Interscience, New York, 1955, pp. 241-261.

11. Heggestad, H. E., and Bowman, D. R.: Burley tobacco quality, yield and chemical composition as affected by time of harvest; Tenn. Agr. Exp. Sta. Bull. 1953, 230.

12. McMurtrey, J. E., Jr., Bacon, C. W., and Ready, D.: Growing tobacco as a source of nicotine; U.S.D.A. Tech. Bull. 1942, 820.

13. Steffens, G. L., and Street, O. E.: Effect of winter cover crops on growth, quality and nitrogen nutrition of Maryland tobacco; Md. Agr. Exp. Sta. Bull. 1957, A-86.

14. Tso, T. C.: Micro- and secondary elements in tobacco; Bot. Bull. Acad. Sinaca 7 (1966) 28-63.

The authors' address:

University of Maryland, College of Agriculture, Department of Agronomy, College Park, Maryland, 20742, USA. 